\title{
EFFECT OF CALCIUM CHLORIDE, CALCIUM LACTATE AND HYDROGEN PEROXIDE TREATMENTS ON QUALITY OF FRESH CUT CANTALOUPE DURING COLD STORAGE
}

\author{
ATTIA, MANAL M. \\ Postharvest and Handling of Vegetable Crops Department. Horticulture Research \\ Institute. ARC, Giza, Egypt.
}

(Manuscript received 3 July 2014)

\begin{abstract}
This study was carried out on cantaloupe fruits (Cucumis melo L. Cv. Primal, Galia group) harvested at light yellow color stage from a private farm at Fayed district, Ismailia Governorate during 2011/2012 and 2012/2013 seasons, to evaluate the effects of post - cut dipping in solutions of $\mathrm{Cacl}_{2}(0.5 \%, 1 \%)$, Ca-lactate (1\%, $2 \%), \mathrm{H}_{2} \mathrm{O}_{2}(0.15,0.30 \%)$ and distillate water (control) for maintaining quality of fresh- cut product. Results showed that fresh - cut cantaloupe dipped in solutions of calcium chloride at $0.5 \%$, calcium lactate at $1 \%$ and $\mathrm{H}_{2} \mathrm{O}_{2}$ at $0.15 \%$ were the most effective treatments for maintaining general appearance during storage and maintaining color close to initial expressed as (Land $b$ values). Fresh - cut cantaloupe treated with $\mathrm{Cacl}_{2}$ at 0.5 or $1 \%$, Ca-lactate at $1 \%$ and $\mathrm{H}_{2} \mathrm{O}_{2}$ at $0.15 \%$ reduced the incidence of discoloration compared to control $\mathrm{Cacl}_{2}(0.5 \%)$, Ca-lactate $(1 \%)$ and $\mathrm{H}_{2} \mathrm{O}_{2}$ at $0.15 \%$ gave typical flavor till the end of storage period while using $\mathrm{CaCl}_{2}$ at $1 \%$ Ca-lactate at $2 \%$ independently gave a slight change in flavor. $\mathrm{CaCl}_{2}$ at $0.5 \%$ or ca-lactate at $1 \%$ reduced the loss of texture. Fresh cut cantaloupe treated with $\mathrm{Cacl}_{2}$ at 0.5 or $1 \%$, Calactate at $1 \%$ and $\mathrm{H}_{2} \mathrm{O}_{2}$ at $0.15 \%$ seems to be the most effective in reducing the total sugar loss.

Concerning total phenolic content, all used treatments maintained the total phenolic compounds compared with the control, however, fresh-cut cantaloupe dipped in solutions of $\mathrm{Cacl}_{2}$ at $0.5 \%$ or $1 \%$ and Ca-lactate at $1 \%$ were the most effective treatments in reducing phenolic compounds loss, while $2 \% \mathrm{Ca}$ lactate and $\mathrm{H}_{2} \mathrm{O}_{2}$ with the two concentrations were less effective in reducing total phenolic loss. $\mathrm{Cacl}_{2}$ and Ca-lactate at the two concentrations were more effective in delaying PPO activity in fresh- cut cantaloupe during storage. Fresh- cut cantaloupe dipped in $\mathrm{CaCl}_{2}$ at 0.5 and $1 \%$ or Ca-lactate at $1 \%$ and $\mathrm{H}_{2} \mathrm{O}_{2}$ at $0.15 \%$ provided the lowest count in all types of microorganisms but Calactate at $2 \%$ or $\mathrm{H}_{2} \mathrm{O}_{2}$ at 0.30 were less effective in reducing this character.
\end{abstract}

\section{INTRODUCTION}

Shelf life extension of fresh cut product is relevant for the industry because of its economic impact. It is important that treatments applied to fresh- cut fruits help maintain their appearance (i.e. color, integrity, absence of excessive drippings in the package) as this is the first characteristic a consumer perceives as quality of the product. However, 
parallel to maintaining adequate appearance and texture of the product, potential treatments showed negatively affect fresh-cut flavor or jeopardize microbiological safety. To minimize these effects, it is necessary to use some techniques in conjunction with low temperature to fresh - cut fruits.

Fresh - cut cantaloupe shelf life may be extended by using calcium chloride and calcium lactate dips(Luna- Guzman and Barrett,2000) or hydrogen peroxide dips (Ukuku et al., 2005).

Calcium chloride dips can maintain visual quality resulting in a longer shelf life of fresh- cut cantaloupe(Luna- Guzman and Barrett, 2000), $\mathrm{Cacl}_{2}$ dips retarded flesh softening in fresh-cut cantaloupe and improved its shelf life (Garcia and Barrett,2002) and also inhibited lipase activity in cantaloupe, maintained fleshness and reduced decay (Lamikrana and Watson, 2007).

Calcium lactate represents an alternative calcium source because it avoids the bitterness or off flavors associated with that salt and the antibacterial properties (Rodrigus et al.,2010). Calcium lactate $(0.5-2 \%)$ has been used as a firming agent for processed cantaloupe (Luna-Guzman and Barrette, 2000). The use of calcium lactate may import bitterness or flavor differences (Rodrigues et al., 2010). Following the dip treatment, a residual amount of calcium lactate remains on the surface of the product, thus increasing likeliness of bitterness detection by the consumer. Postharvest application of calcium lactate lowered respiration and moisture loss rates, and increased firmness, reduced incidence of physiological disorder and decay (Lamikrana and Watson, 2007).

Postharvest treatments with hydrogen peroxide have been proposed as alternative to chemical treatments. The use of $\mathrm{H}_{2} \mathrm{O}_{2}$ for disinfecting vegetables appeared to reduce microbial populations on fresh products and extend the shelf life without leaving significant residues or causing loss of quality (Sapres et al., 2001). Fresh - cut melon dipped in solution of $\mathrm{H}_{2} \mathrm{O}_{2}$ improved general appearance, extending fruit shelf life and high reduction of decay (Ukuku, 2004).

The objective of this study was to investigate the potential of calcium chloride, calcium lactate and hydrogen peroxide individually in different concentrations, to extend the shelf life and maintain the quality of fresh - cut cantaloupe.

\section{MATERIALS AND METHODES}

Cantaloupe plants (Cucumis melo L. cv.Primal Galia group) were grown under tunnels in private farm at Fayed district, Ismailia Governorate in the winter of 2011/2012 and 2012/2013 seasons. The fruits were harvested at light yellow color stage (color stage 4) according to Fallik et. al. (2001) on April 26 and 23 in 2012 and 2013 seasons, 
respectively. Then transported to laboratory of Handling of Vegetable Crops Department, Giza Governorate and were kept overnight at $25^{\circ} \mathrm{C}$ and $95 \%$ relative humidity (RH). The following day fruits for were selected with uniformity of size, color and free of visual damage or defects.

All cutting utensils used (knife, cutting board) were washed with soap and water and rinsed with 1000 ppm sodium hypochlorite solution prior to use.

Cantaloupe fruits were cut longitudinally and two halves, seeds were removed and the fruits were then cut into 8 equal parts and were dipped into 50ppm sodium hypochlorite $(\mathrm{pH} 7)$ for 30 seconds. The skin was removed and every part was approximately $2-2.2 \mathrm{~cm}$ thickness and weighed $70.75 \mathrm{gram}$. the samples of fresh-cut cantaloupe were randomly divided into 7 groups for the following treatments.

1. Dipping in solution of calcium chloride at concentrations of 0.5 and $1 \%$ for $5 \mathrm{~min}$.

2. Dipping in solution of calcium lactate at concentrations of 1 and $2 \%$ for $5 \mathrm{~min}$.

3. Dipping in solution of hydrogen peroxide at concentrations of $0.15 \%$ and 0.30 \%for 5 min.

4. Control (dipping in distillate water for $5 \mathrm{~min}$ ).

All samples of fresh- cut cantaloupe were air dried, placed in polystyrene trays, wrapped with polypropylene film and each had $250 \mathrm{~g}$ represented as one replicate, twelve replicates for each treatment were stored at $3{ }^{\circ} \mathrm{C}$ and $95 \% \mathrm{RH}$ for 12 days. Samples were taken at random in 3 replicates and the samples were arranged in complete randomized design.

Measurements were examined immediately after treatment and every 3- day intervals to determine:

1. General appearance(GA) was evaluated using scale from 9 to 1 , where $9=$ excellent, $7=$ good, $5=$ fair, $3=$ poor, $1=$ unusable, and fruits rating below 5 were considered unmarketable.

2. Color was evaluated by a color difference meter (Minolta CR200) to measure the $L$ and $b$ values.

3. Discoloration was evaluated as a scale of 1 to 5 where $1=$ non, $2=$ slight, $3=$ moderate, $4=$ severe and $5=$ extra severe.

4. Flavor was evaluated as a scale of 1 to 5 where $1=$ none, $2=$ slight, $3=$ moderate, $4=$ moderately severe and $5=$ full typical taste.

5. Texture was recorded by TA- 1000 texture analyzer instrument using a penetrating cylinder of $1 \mathrm{~mm}$ diameter, to a constant distance ( 3 and $5 \mathrm{~mm}$ ) inside the pulp of fresh- cut slices and by a constant speed $2 \mathrm{~mm}$ per sec., and the peak of resistance was recorded.

6. Total sugars \% were measured according to Somogyi (1952) and Nelson (1974). 
7. Total phenolic content: Dry defeated crushed fresh -cut cantaloupe pieces (1.0 g) were macerated in $5-10 \mathrm{ml} 80 \%$ ethanol for at least 24 hours at $0^{\circ} \mathrm{C}$. The remaining residue was re- extracted with $5-10 \mathrm{ml}$ of $80 \%$ ethanol three times. The phenolic content was determined by the modified colorimetric method using Folin- Ciocalteau reagent. The reagent was diluted (1:10 with distilled water) then $0.75 \mathrm{ml}$ was added to the extracts $(0.1 \mathrm{ml})$ in test tubes. The mixture was mixed and allowed to stand at room temperature for $5 \mathrm{~min}$. then $0.75 \mathrm{ml}$ of $6 \%$ $(w / v)$ sodium carbonate solution was added and mixed. After 90 min. at room temperature, the absorbance was recorded at $765 \mathrm{~nm}$. The standard curve was prepared by gallic acid $(0-250 \mathrm{mg} / \mathrm{L}$ in aqueous methanol $(50 \%)$. The total phenols were expressed as chlorogenic acid equivalents $(\mathrm{mg} / 100 \mathrm{gm}$ fresh weight) AOAC (1990).

8. Poly phenol oxidase (ppo) assay: were determined according to Dogan et al.(2002) and expressed as percentage of the activity of the respective zero time.

The poly phenol oxidase (ppo) was extracted by homogenizing treated or untreated vegetable samples with 1-5 fold their weight sodium phosphate buffer $(0.1 \mathrm{~m}, \mathrm{pH} 6.5)$ containing $30 \mathrm{mM}$ sodium ascorbate and $0.4 \mathrm{M}$ sucrose at $25^{\circ} \mathrm{C}$. The crude extraction was filtered and refrigerated till used within $24 \mathrm{~h}$. Catechol as substrate $(3 \mathrm{~mL}, 10.0 \mathrm{mM})$ dissolved in the phosphate buffer was mixed with $1.0 \mathrm{~mL}$ enzyme extract. All of the enzymatic reactions were kept at the optimum condition (substrate saturation, $\mathrm{pH} 6.5$ and $25^{\circ} \mathrm{C}$.)

The increase in absorbance of 0.01 per min. at $495 \mathrm{~nm}$ at the specified condition was defined as one unit of ppo activity. The results were expressed as percentage of the activity of the respective zero experiment (Dogan et al.,2002)

9. Total microbial count: Each sample was prepared by homogenizing $10 \mathrm{gm}$ of sliced cantaloupe with $100 \mathrm{ml}$ sterile 0.1 peptone water for $2 \mathrm{~min}$. Dilution by 0.1 pepton water was made as needed in Plate Count Agar (PCA) and incubated for $24 \mathrm{hr}$ at $37^{\circ} \mathrm{C}$ for the determination of meso-sphilic aerobic microorganisms. Viable counts were determined by counting the number of colonies and reported as colony forming units per gram, CFU / g (Anese and Nicoli, 1997)

All data were subjected to the statistical analysis according to the method described by Senedecor and Cochran (1980). 


\section{RESULTS AND DISCUSSION}

\section{1) General appearance(GA):}

Data in Table (1): showed that general appearance decreased with the prolongation of storage period. Similar results were reported by (Luna-Guzman and Barrett, 2000) on fresh cut cantaloupe. Significant differences were found between postharvest treatments in general appearance (GA) of fresh - cut cantaloupe during storage. All treatments were better than control, however, fresh - cut cantaloupe dipped in solution of calcium chloride, at $0.5 \%$, calcium lactate at $1 \%$ and hydrogen peroxide at $0.15 \%$ were the most effective treatments for maintaining GA during storage. These results agree with those of Luna-Guzman and Barrett (2000) for $\mathrm{CaCl}_{2}$ and Ca- lactate and Ukuku et. al., (2005) for $\mathrm{H}_{2} \mathrm{O}_{2}$.

This may be due to that calcium treatment $\left(\mathrm{Cacl}_{2}\right)$ delayed senescence of fresh cut cantaloupe (Lamikrana and Watson, 2007) and $\mathrm{H}_{2} \mathrm{O}_{2}$ reduce weight loss and rot rate of fresh- cut cantaloupe (Ukuku et al.,2005). In the same time, ethylene production by fresh - cut melon can be reduced by $\mathrm{H}_{2} \mathrm{O}_{2}$ and this reduction keeps the appearance of fruits in best condition (Ukuku 2004).

The interaction between postharvest treatments and the storage period revealed that fresh- cut cantaloupe dipped in $\mathrm{Cacl}_{2}$ at $0.5 \%$ and Ca-lactate at $1 \%$ showed the best appearance, it did not exhibit any changes in their appearance till the end of storage period (12 days). While using $\mathrm{H}_{2} \mathrm{O}_{2}$ rated good appearance of the same period, $\mathrm{Cacl}_{2}$ or Ca-lactate or $\mathrm{H}_{2} \mathrm{O}_{2}$ at higher concentrations rated good appearance after 6 days of storage and dropped too slightly below the fair level at the end of storage. On the other hand, untreated control product had the poorest appearance at the end of storage.

\section{2) Discoloration}

Data in Table (1) showed that there was an increment in discoloration for the cut surface of cantaloupe as the storage period was prolonged. The change in color development is related primarily to the oxidation of phenolic compounds to o- quinines, a reaction catalyzed by poly phenol oxidase. Quinones then polymerize to dark brown, black or red polymers (Sapers and Hicks,1989)

Data also show that all the used treatments reduced the incidence of discoloration compared to control, and the fresh - cut cantaloupe treated with $\mathrm{Cacl}_{2}$ at the two concentrations, Ca-lactate at $1 \%$ and $\mathrm{H}_{2} \mathrm{O}_{2}$ at $0.15 \%$ were the most effective treatments in this concern. Ca-lactate at $2 \%$ and $\mathrm{H}_{2} \mathrm{O}_{2}$ at $0.30 \%$ were less effective. These results were true in the two seasons and agree with those of Luna-Guzman and Barrett(2000)for $\mathrm{CaCl}_{2}$ and Ca-lactate, Ukuku et. al. (2004)for $\mathrm{H}_{2} \mathrm{O}_{2}$ and Qlusola and 
Watson (2007). They found that $\mathrm{CaCl}_{2}$ or Ca-lactate, $\mathrm{H}_{2} \mathrm{O}_{2}$ prevented discoloration in the cut surface of fresh- cut cantaloupe.

The reduction in discoloration in cut surface of cantaloupe may be due to that $\mathrm{Cacl}_{2}$ or Ca-lactate treatments reduced poly phenol oxidase activity and preserved the total phenolic content and reduced the color change of cut surface of cantaloupe LunaGuzman and Barrett, (2000).

Regarding the interaction between postharvest treatments and storage period on the discoloration, data revealed that fresh- cut cantaloupe dipped in $\mathrm{Cacl}_{2}$ at the two concentrations, Ca-lactate at $1 \%$ and $\mathrm{H}_{2} \mathrm{O}_{2}$ at $0.15 \%$ did not show any changes in their color till the end of storage (12 days). However, Ca-lactate at $2 \%$ or $\mathrm{H}_{2} \mathrm{O}_{2}$ at $0.30 \%$ treatment gave a slight score after the same period and the untreated (control) resulted in severe discoloration with the highest score; these results were true for the two seasons.

\section{3) Color:}

The color of fresh- cut cantaloupe was analyzed recording $L$ and $b$ values. Table (2) showed that there was a significant decrease for all treatments, indicating that the browning process of cut surface developed and reached darker with storage. The best results were observed for fresh - cut cantaloupe dipped in solution of $\mathrm{CaCl}_{2}$ at $0.5 \%$ or $1 \%$, Ca-lactate at $1 \%$ and $\mathrm{H}_{2} \mathrm{O}_{2}$ at $0.15 \%$ which the $\mathrm{L}$ value remained close to initial value during storage, resulted in higher color ( high $L$ value), while fresh-cut cantaloupe treated with distilled water (control) had darker color (low $L$ value) Table (2). These results agree with Francisca et .al. (2008) who found that Cacl2, presented the highest $\mathrm{L}$ values, and were lighter than the other treatments. In general values of $b$ decreased during storage period. However, fresh- cut cantaloupe dipped in solution of $\mathrm{Cacl}_{2}$ at 0.5, Ca-lactate at $1 \%$ and $\mathrm{H}_{2} \mathrm{O}_{2}$ at $0.15 \%$ presented a small decrease in $\mathrm{b}$ values, preserving most of the yellow purity at the end of the storage period (12 days), while for control treatment, b values decreased from 46.9 , at processing to 39.35 at the end of storage (average of the two seasons).

Indeed, with these treatments the color of (yellow) fresh- cut was kept stable throughout storage, with significantly less browning than the other treatments. The results suggested that this treatment is a potential alternative preserve the initial color of fresh-cut cantaloupe and protect against browning.

\section{4) Flavor:}

Data in Table (3) showed that all used treatments did not present apparent changes in their taste till six days of storage and gave typical flavor fresh- cut cantaloupe treated with $\mathrm{CaCl}_{2}$ at $0.5 \%$, Ca-lactate at $1 \%$ and $\mathrm{H}_{2} \mathrm{O}_{2}$ at $0.15 \%$ till the end of the storage period (12 days), while, in general, using $\mathrm{CaCl}_{2}$ at $1 \%$ Ca-lactate at $2 \%$ or $\mathrm{H}_{2} \mathrm{O}_{2}$ 
at $0.30 \%$ independently gave a slight change. Moreover, untreated fruit (control) resulted in moderate score after 12 days of storage. These results were true for the two seasons. These results were agree with those of Luna-Guzman and Barrett (2000) who found that typical melon flavor was significantly more detectable in $\mathrm{Ca}$-lactate or $\mathrm{Cacl}_{2}$ treated fresh- cut cantaloupe.

\section{5) Texture:}

Data in Table (3) indicated that texture decreased continuously with extending the storage period in the different treatments used. These results were true in the two seasons and agree with those of Lamikrana and Watson, (2007) on fresh -cut cantaloupe. The decline in fruit texture may be due to the gradual breakdown of protopectin to lower molecular fractions which are more soluble in water and this is directly correlated with the softening of the fruits.(Wills et. al.,1981).

The obtained data revealed that the various applied treatments gave significantly greater fruit texture as compared with untreated (control) treatment. However, fresh- cut cantaloupe dipped in solution of $\mathrm{CaCl}_{2}$ at $0.5 \%$ or Ca-lactate at $1 \%$ were the most effective treatments in reducing the loss of texture during storage with no significant differences between them in the two seasons, followed by $\mathrm{H}_{2} \mathrm{O}_{2}$ at $0.15 \%$. The lowest value of texture was found in untreated control. These results were true in the two seasons and agree with those of Luna-Guzman and Barrett (2000) who found that fresh-cut cantaloupe dipped in $\mathrm{Cacl}_{2}$ or $\mathrm{Ca}$ - lactate reduced the loss of texture during storage.

The favorable effect of Ca-lactate or $\mathrm{Cacl}_{2}$ could be due to that the calcium maintain the cell wall structure in fruit by interacting with pectins in the cell wall to form calcium pectate which assists molecular bonding between constituents of cell wall (Degrave et. al., 2003) ; Calcium also increases cell wall turgor pressure and stabilizers the cell membrane (Luna- Guzman and Barrett, 2000). Also, the free carboxylic acid liberated by pectinmethyl esterase can interact with calcium to form a molecular network which results in an improvement in firmness (Degrave et. al., 2003).

Regarding the interaction between postharvest treatments application and storage period, data indicate that fresh- cut cantaloupe treated with $\mathrm{Cacl} 2$ at $0.5 \%$ or ca-lactate at $1 \%$ was the most obvious in maintaining fresh-cut cantaloupe texture after 12 days of storage.

\section{6) Total sugars:}

Data in Table (4) showed that total sugar content of fresh- cut cantaloupe was decreased as the storage period was extended. The decrease of this content is probably due to the consumption of sugars through respiration (Wills et. al.1981). 
All tested treatments reduced the total sugar loss as compared with control, dipping fresh- cut cantaloupe in $\mathrm{Cacl}_{2}$ at the two concentrations, Ca-lactate at $1 \%$ and $\mathrm{H}_{2} \mathrm{O}_{2}$ at $0.15 \%$ seems to be the most effective in reducing the total sugar loss. Ca-lactate at $2 \%$ and $\mathrm{H}_{2} \mathrm{O}_{2}$ at $0.30 \%$ were less effective in this concern. Similarly, Lamikrana and Watson, 2007 found that dipping fresh- cut cantaloupe in $\mathrm{Cacl}_{2}$ induces a delay in consumption of sugar during storage with no detrimental effect on consumer acceptance.

In general, the interaction between postharvest treatments and storage period were significant in the two seasons. Fresh- cut cantaloupe dipped in solution of $\mathrm{CaCl}_{2}$ at 0.5 or $1 \%$, Ca-lactate at $1 \%$ and $\mathrm{H}_{2} \mathrm{O}_{2}$ at $0.15 \%$ resulted in the highest total sugar content after 12 days of cold storage at $4^{\circ} \mathrm{C}$. While, untreated (control) gave the lowest ones at the same period.

\section{7) Total phenolic content:}

Data in Table (4) show that the total phenolic content was decreased with the prolongation of storage period. This decrease is probably due to the oxidation by poly phenol oxidase (PPO) (Yamaguchi et al., 2003), it is also reported that quercetin was oxidized directly by PPO. Moreover, Rabards et. al. (1999) found that phenolic compounds have a significant role oxidation processes as antioxidants and as substrates in browning reactions.

Concerning the tested postharvest treatments, data show that all treatments maintained the total phenolic compounds compared with the control. The dipping in solutions of $\mathrm{CaCl}_{2}$ at $0.5 \%$ or $1 \%$ and Ca-lactate at $1 \%$ were the most effective treatments in reducing phenolic compounds loss.The higher concentration from Calactate and the two concentrations of $\mathrm{H}_{2} \mathrm{O}_{2}$ were less effective in reducing total phenolic loss. These results agree with those obtained by Altunkaya and Gokmen (2009) on lettuce who found that the rate of degradation of individual phenolic compounds decreased during storage when $\mathrm{Cacl}_{2}$ was added. Acidification of samples appeared to have an important function to stabilize phenolic compounds in product.

In general, there were significant differences between postharvest treatments and storage period. The lowest value of total phenolic content was observed at the end of storage period (12 days), while the highest one of this compound was found in freshcut cantaloupe treated with $\mathrm{Cacl}_{2}$ at 0.5 or $1 \%$ treatment. These results hold true in the two seasons. 


\section{8) Poly phenol oxidase (PPO) activity:}

Data in Table (5) showed that PPO activity of fresh - cut cantaloupe was high on zero time storage day and then increased with the prolongation of the storage period. Also, data in the same Table show that immediately after processing, PPO activity was decreased among various applied treatments than the control ones (which obtained the maximum activity $100 \%)$. The increase of PPO activity in control treatment after cutting is mainly due to activation process from latent to fully active form. In fact, as previously reported by Canto et. al. (2001) tissue wounding involves the decompart metallization of cellular components with the subsequent release of proteases involving a cascade of reactions leading to the activation of latent PPO.

All studied treatments reduced the activity of PPO during storage if compared with control. $\mathrm{CaCl}_{2}$ and $\mathrm{Ca}$-lactate at the two concentrations were more effective in delaying PPO activity in fresh- cut cantaloupe during storage. These results agree with finding of Mayer and Harel (1991) who found that $\mathrm{Cacl}_{2}$ decreased $\mathrm{pH}$.and the reduction in PPO activity was associated with this decrease. Also calcium reduced PPO activity through complexation with copper at the active site of the enzyme.

The interaction between treatments and storage period indicated that after 12 days of storage PPO activity for the control treatment, $\mathrm{CaCl}_{2}$ at $0.5 \%$ and $1 \%$,Ca-lactate at $1 \%$ or $2 \%$ and $\mathrm{H}_{2} \mathrm{O}_{2}$ at $0.15 \%$ and $0.30 \%$ were $124.25,97.35,98,99.65$, $100.65,104.05,112.95$ (average in the two seasons)respectively.

\section{9) Total microbial count:}

Data in Table (5) showed that microbial growth in fresh- cut cantaloupe increased with increasing the storage period particularly in untreated (control) treatment. These results were true in the two seasons, similar results were reported by LunaGuzman and Barrett (2000) and Ukuku et. al. (2005), on fresh- cut cantaloupe. Significant differences in microorganism growth were found between postharvest treatments and untreated (control).

The fresh- cut cantaloupe treated with all used postharvest treatments had lower level of microbial load in comparison to control treatment. Fresh- cut cantaloupe dipped in $\mathrm{CaCl}_{2}$ at 0.5 and $1 \%$ or Ca-lactate at $1 \%$ and $\mathrm{H}_{2} \mathrm{O}_{2}$ at $0.15 \%$ provided the lowest count in all types of microorganisms with no significant differences between them in the first season. Ca-lactate at $2 \%$ or $\mathrm{H}_{2} \mathrm{O}_{2}$ at 0.30 was less effective in reducing this character. These results were agree with those of Luna-Guzman and Barrett (2000) who 
stated that $\mathrm{CaCl}_{2}$ or Ca- lactate have provided an inhibitory effect on microbial growth, while control treatment allowed for spore spreading and actually increased counts. Ukuku et .al. (2005) found that the use of $2.5 \% \mathrm{H}_{2} \mathrm{O}_{2}$ as postharvest dipping caused significant reduction in populations of aerobic mesophilic, yeast and mold on cantaloupe surface.

Calcium chloride or calcium lactate can lower interacellular $\mathrm{pH}$ or reduce water activity (Shelef, 1994) which provides a protective antimicrobial barrier against food borne pathogens in products (Weaver and Shelef, 1993).

Also, microflora is usually restricted to lactic acid bacteria when $\mathrm{pH}$ was low (Luna-Guzman and Barrett, 2000). Calcium chloride enhance tissue resistance to bacterial attach by stabilizing or strengthening cell walls (Mayer and Harel, 1991). For calcium compound, it was reported that the antimicrobial property was due to calcium ability to uncouple microbial transport processes (Saftner et al.,2003).

In general, the interaction between postharvest treatments and storage period was significant during all storage periods. After 12 days of storage, data showed that fresh-cut cantaloupe treated with $\mathrm{Cacl}_{2}$ at 0.5 or $1 \%$, Ca-lactate at $1 \%$ and $\mathrm{H}_{2} \mathrm{O}_{2}$ at 0.15 $\%$ were effective in inhibition of bacterial growth.

\section{CONCLUSION}

From the previous results it could be concluded that fresh- cut cantaloupe dipped in $\mathrm{CaCl}_{2}$ at 0.5 , Ca-lactate at $1 \%$ and $\mathrm{H}_{2} \mathrm{O}_{2}$ at $0.15 \%$ was the most effective treatments in inhibiting browning of cut surfaces (indicating by higher value of $b$ value), reducing total microbial count, reducing total phenolic loss and maintained quality (texture, color, flavor and sugars . In addition, these treatments gave fruits with good appearance for 12 days at $4^{\circ} \mathrm{C}$ and $95 \% \mathrm{R} \mathrm{H}$. 
Table 1. Effect of $\mathrm{CaCl}_{2}$, $\mathrm{Ca}$ - lactate and $\mathrm{H}_{2} \mathrm{O}_{2}$ concentrations on General appearance and Discoloration of fresh - cut cantaloupe.

\begin{tabular}{|c|c|c|c|c|c|c|c|c|c|c|c|c|}
\hline \multirow{3}{*}{ Treatment (T) } & \multicolumn{5}{|c|}{$2011 / 2012$} & \multirow{3}{*}{ Mean } & \multicolumn{5}{|c|}{$2012 / 2013$} & \multirow{3}{*}{ Mean } \\
\hline & \multicolumn{5}{|c|}{ Storage period days (SP) } & & \multicolumn{5}{|c|}{ Storage period days (SP) } & \\
\hline & $\mathbf{0}$ & 3 & 6 & 9 & 12 & & $\mathbf{0}$ & 3 & 6 & 9 & 12 & \\
\hline \multicolumn{13}{|c|}{ General appearance(Score) } \\
\hline $\mathrm{CaCl}_{2}$ at $0.05 \%$ & 9.00 & 9.00 & 9.00 & 9.00 & 8.33 & 8.87 & 9.00 & 9.00 & 9.00 & 8.33 & 8.33 & 8.73 \\
\hline $\mathrm{CaCl}_{2}$ at $1 \%$ & 9.00 & 9.00 & 8.33 & 6.33 & 3.67 & 7.27 & 9.00 & 9.00 & 9.00 & 6.33 & 4.33 & 7.53 \\
\hline Ca-lactate at $1 \%$ & 9.00 & 9.00 & 9.00 & 9.00 & 8.33 & 8.87 & 9.00 & 9.00 & 9.00 & 9.00 & 8.33 & 8.87 \\
\hline Ca-lactate at $2 \%$ & 9.00 & 9.00 & 9.00 & 6.33 & 4.33 & 7.53 & 9.00 & 9.00 & 9.00 & 7.00 & 4.33 & 7.67 \\
\hline $\mathrm{H}_{2} \mathrm{O}_{2}$ at $0.15 \%$ & 9.00 & 9.00 & 8.33 & 7.67 & 7.00 & 8.20 & 9.00 & 9.00 & 9.00 & 8.33 & 7.67 & 8.60 \\
\hline $\mathrm{H}_{2} \mathrm{O}_{2}$ at $0.3 \%$ & 9.00 & 9.00 & 8.33 & 6.33 & 4.33 & 7.40 & 9.00 & 9.00 & 8.33 & 7.67 & 7.00 & 8.20 \\
\hline Cont. & 9.00 & 7.00 & 6.33 & 3.00 & 1.00 & 5.27 & 9.00 & 7.67 & 6.33 & 3.33 & 2.33 & 5.73 \\
\hline Mean & 9.00 & 8.71 & 8.33 & 6.81 & 5.28 & 7.63 & 9.00 & 8.81 & 8.52 & 7.14 & 6.05 & 7.90 \\
\hline \multirow{2}{*}{$\begin{array}{c}\text { LSD at } 0.05 \\
\text { level for }\end{array}$} & $\mathbf{T}$ & SP & $\mathbf{T} * \mathbf{S P}$ & & & & $\mathbf{T}$ & SP & $\mathbf{T} * \mathbf{S P}$ & & & \\
\hline & 0.28 & 0.30 & 0.42 & & & & 0.22 & 0.27 & 0.31 & & & \\
\hline \multicolumn{13}{|c|}{ Discoloration (Score) } \\
\hline $\mathrm{CaCl}_{2}$ at $0.05 \%$ & 1.00 & 1.00 & 1.00 & 1.00 & 1.00 & 1.00 & 1.00 & 1.00 & 1.00 & 1.00 & 1.00 & 1.00 \\
\hline $\mathrm{CaCl}_{2}$ at $1 \%$ & 1.00 & 1.00 & 1.00 & 1.00 & 1.33 & 1.07 & 1.00 & 1.00 & 1.00 & 1.00 & 1.33 & 1.07 \\
\hline Ca-lactate at $1 \%$ & 1.00 & 1.00 & 1.00 & 1.00 & 1.33 & 1.07 & 1.00 & 1.00 & 1.00 & 1.00 & 1.00 & 1.00 \\
\hline Ca-lactate at $2 \%$ & 1.00 & 1.00 & 1.00 & 1.33 & 2.00 & 1.27 & 1.00 & 1.00 & 1.00 & 1.33 & 2.33 & 1.33 \\
\hline $\mathrm{H}_{2} \mathrm{O}_{2}$ at $0.15 \%$ & 1.00 & 1.00 & 1.00 & 1.00 & 1.32 & 1.06 & 1.00 & 1.00 & 1.00 & 1.00 & 1.33 & 1.07 \\
\hline $\mathrm{H}_{2} \mathrm{O}_{2}$ at $0.3 \%$ & 1.00 & 1.00 & 1.00 & 1.00 & 2.33 & 1.27 & 1.00 & 1.00 & 1.00 & 1.00 & 2.33 & 1.27 \\
\hline Cont. & 1.00 & 1.33 & 2.00 & 3.00 & 4.00 & 2.27 & 1.00 & 1.00 & 2.33 & 3.33 & 4.33 & 2.40 \\
\hline Mean & 1.00 & 1.05 & 1.14 & 1.33 & 1.90 & 1.28 & 1.00 & 1.00 & 1.19 & 1.38 & 1.95 & 1.30 \\
\hline \multirow{2}{*}{ LSD at 0.05 level for } & $\mathrm{T}$ & SP & $\mathrm{T} * \mathrm{SP}$ & & & & $\mathrm{T}$ & SP & $\mathrm{T} * \mathrm{SP}$ & & & \\
\hline & 0.08 & 0.09 & 0.10 & & & & 0.07 & 0.20 & 0.22 & & & \\
\hline
\end{tabular}


Table 2. Effect of Cacl2, Ca- lactate and H2O2 concentrations on Color ( $\mathrm{H}$ and b values) of fresh - cut cantaloupe.

\begin{tabular}{|c|c|c|c|c|c|c|c|c|c|c|c|c|}
\hline \multirow{3}{*}{$\begin{array}{l}\text { Treatment } \\
\text { (T) }\end{array}$} & \multicolumn{5}{|c|}{$2011 / 2012$} & \multirow{3}{*}{ Mean } & & & $12 / 20$ & & & \multirow{3}{*}{ Mean } \\
\hline & \multicolumn{5}{|c|}{ Storage period days (SP) } & & \multicolumn{5}{|c|}{ Storage period days (SP) } & \\
\hline & 0 & 3 & 6 & 9 & 12 & & 0 & 3 & 6 & 9 & 12 & \\
\hline \multicolumn{13}{|c|}{ L values } \\
\hline $\begin{array}{l}\mathrm{Cacl}_{2} \text { at } \\
0.05 \%\end{array}$ & 55.20 & 55.10 & 54.80 & 54.60 & 54.10 & 54.76 & 49.90 & 49.20 & 49.00 & 48.80 & 48.90 & 49.06 \\
\hline $\begin{array}{c}\mathrm{Cacl}_{2} \text { at } 1 \\
\%\end{array}$ & 55.20 & 54.80 & 54.20 & 53.70 & 53.00 & 54.18 & 49.40 & 49.00 & 48.80 & 48.10 & 47.80 & 48.62 \\
\hline $\begin{array}{c}\text { Ca-lactate } \\
\text { at } 1 \%\end{array}$ & 55.20 & 54.90 & 54.70 & 54.40 & 54.00 & 54.64 & 49.40 & 49.10 & 48.90 & 48.60 & 48.10 & 48.82 \\
\hline $\begin{array}{c}\text { Ca-lactate } \\
\text { at } 2 \%\end{array}$ & 55.20 & 54.60 & 54.00 & 53.40 & 52.80 & 54.00 & 49.40 & 48.60 & 48.00 & 47.10 & 46.30 & 47.88 \\
\hline $\begin{array}{l}\mathrm{H}_{2} \mathrm{O}_{2} \text { at } \\
0.15 \%\end{array}$ & 55.20 & 54.80 & 54.60 & 54.30 & 53.90 & 54.56 & 49.40 & 48.90 & 48.60 & 48.30 & 48.00 & 48.64 \\
\hline $\begin{array}{c}\mathrm{H}_{2} \mathrm{O}_{2} \text { at } \\
0.3 \%\end{array}$ & 55.20 & 54.50 & 54.00 & 53.30 & 52.40 & 53.88 & 49.40 & 48.10 & 47.50 & 46.80 & 46.00 & 47.56 \\
\hline Cont. & 55.20 & 54.00 & 53.40 & 51.10 & 49.10 & 52.56 & 49.40 & 47.10 & 46.20 & 44.20 & 42.30 & 45.84 \\
\hline Mean & 55.20 & 54.67 & 54.24 & 53.54 & 52.76 & 54.08 & 49.40 & 48.57 & 48.14 & 47.41 & 46.77 & 48.06 \\
\hline \multirow{2}{*}{$\begin{array}{c}\text { LSD at } 0.05 \\
\text { level for }\end{array}$} & $\mathrm{T}$ & SP & $\mathrm{T}^{*} \mathrm{SP}$ & & & & $\mathrm{T}$ & $\mathrm{SP}$ & $\mathrm{T} * \mathrm{SP}$ & & & \\
\hline & 0.13 & 0.17 & 0.19 & & & & 0.23 & 0.24 & 0.26 & & & \\
\hline \multicolumn{13}{|c|}{ b values } \\
\hline $\begin{array}{l}\mathrm{Cacl}_{2} \text { at } \\
0.05 \%\end{array}$ & 45.30 & 45.10 & 45.00 & 44.80 & 44.60 & 44.96 & 48.50 & 48.30 & 48.10 & 47.80 & 47.30 & 48.00 \\
\hline $\begin{array}{c}\mathrm{Cacl}_{2} \text { at } 1 \\
\%\end{array}$ & 45.30 & 45.00 & 44.60 & 44.00 & 43.20 & 44.42 & 48.50 & 48.00 & 47.60 & 47.00 & 46.20 & 47.46 \\
\hline $\begin{array}{c}\text { Ca-lactate } \\
\text { at } 1 \%\end{array}$ & 45.30 & 45.00 & 44.90 & 44.70 & 44.40 & 44.86 & 48.50 & 48.10 & 47.90 & 47.60 & 47.10 & 47.84 \\
\hline $\begin{array}{c}\text { Ca-lactate } \\
\text { at } 2 \%\end{array}$ & 45.30 & 44.20 & 43.80 & 43.70 & 43.00 & 44.00 & 48.50 & 47.30 & 47.30 & 46.80 & 46.00 & 47.18 \\
\hline $\begin{array}{l}\mathrm{H}_{2} \mathrm{O}_{2} \text { at } \\
0.15 \%\end{array}$ & 45.30 & 45.00 & 44.70 & 44.50 & 44.00 & 44.70 & 48.50 & 48.00 & 47.70 & 47.30 & 47.00 & 47.70 \\
\hline $\begin{array}{c}\mathrm{H}_{2} \mathrm{O}_{2} \text { at } \\
0.3 \%\end{array}$ & 45.30 & 44.00 & 43.00 & 42.30 & 41.70 & 43.26 & 48.50 & 47.00 & 46.60 & 46.60 & 45.50 & 46.84 \\
\hline Cont. & 45.30 & 43.20 & 41.40 & 40.00 & 38.40 & 41.66 & 48.50 & 46.10 & 44.30 & 42.40 & 40.30 & 44.28 \\
\hline Mean & 45.30 & 44.50 & 43.91 & 43.43 & 42.76 & 43.98 & 48.50 & 47.54 & 47.07 & 46.47 & 45.63 & 47.04 \\
\hline \multirow{2}{*}{$\begin{array}{c}\text { LSD at } 0.05 \\
\text { level for }\end{array}$} & $\mathrm{T}$ & SP & $\mathrm{T} * \mathrm{SP}$ & & & & $\mathrm{T}$ & SP & $\mathrm{T} * \mathrm{SP}$ & & & \\
\hline & 0.12 & 0.17 & 0.22 & & & & 0.14 & 0.18 & 0.24 & & & \\
\hline
\end{tabular}


Table 3. Effect of Cacl2, Ca- lactate and $\mathrm{H} 2 \mathrm{O} 2$ concentrations on Flavor and Texture of fresh - cut cantaloupe.

\begin{tabular}{|c|c|c|c|c|c|c|c|c|c|c|c|c|}
\hline \multirow{3}{*}{$\begin{array}{l}\text { Treatment } \\
\text { (T) }\end{array}$} & \multicolumn{5}{|c|}{ 2011/2012 } & \multirow{3}{*}{ Mean } & \multirow{2}{*}{\multicolumn{5}{|c|}{$\begin{array}{c}2012 / 2013 \\
\text { Storage period days (SP) }\end{array}$}} & \multirow{3}{*}{ Mean } \\
\hline & \multicolumn{5}{|c|}{ Storage period days (SP) } & & & & & & & \\
\hline & $\mathbf{0}$ & 3 & 6 & 9 & 12 & & $\mathbf{0}$ & 3 & 6 & 9 & 12 & \\
\hline \multicolumn{13}{|c|}{ Flavor (score) } \\
\hline $\begin{array}{l}\mathrm{CaCl}_{2} \text { at } \\
0.05 \%\end{array}$ & 5.00 & 5.00 & 5.00 & 5.00 & 5.00 & 5.00 & 5.00 & 5.00 & 5.00 & 5.00 & 5.00 & 5.00 \\
\hline $\begin{array}{c}\mathrm{Cacl}_{2} \text { at } 1 \\
\%\end{array}$ & 5.00 & 5.00 & 5.00 & 4.33 & 4.00 & 4.67 & 5.00 & 5.00 & 5.00 & 4.00 & 3.67 & 4.53 \\
\hline $\begin{array}{c}\text { Ca-lactate } \\
\text { at } 1 \%\end{array}$ & 5.00 & 5.00 & 5.00 & 5.00 & 5.00 & 5.00 & 5.00 & 5.00 & 5.00 & 5.00 & 4.67 & 4.93 \\
\hline $\begin{array}{c}\text { Ca-lactate } \\
\text { at } 2 \% \\
\end{array}$ & 5.00 & 5.00 & 5.00 & 4.67 & 4.00 & 4.73 & 5.00 & 5.00 & 5.00 & 4.33 & 4.00 & 4.67 \\
\hline $\begin{array}{l}\mathrm{H}_{2} \mathrm{O}_{2} \text { at } \\
0.15 \%\end{array}$ & 5.00 & 5.00 & 5.00 & 5.00 & 4.67 & 4.93 & 5.00 & 5.00 & 5.00 & 5.00 & 5.00 & 5.00 \\
\hline $\begin{array}{c}\mathrm{H}_{2} \mathrm{O}_{2} \text { at } \\
0.3 \% \\
\end{array}$ & 5.00 & 5.00 & 5.00 & 4.33 & 3.67 & 4.60 & 5.00 & 5.00 & 5.00 & 4.00 & 3.67 & 4.53 \\
\hline Cont. & 5.00 & 5.00 & 5.00 & 4.00 & 3.33 & 4.47 & 5.00 & 5.00 & 5.00 & 4.33 & 3.00 & 4.47 \\
\hline Mean & 5.00 & 5.00 & 5.00 & 4.62 & 4.24 & 4.77 & 5.00 & 5.00 & 5.00 & 4.52 & 4.14 & 4.73 \\
\hline LSD at 0.05 & $\mathrm{~T}$ & $\mathrm{SP}$ & $\mathrm{T} * \mathrm{SP}$ & & & & $\mathrm{T}$ & SP & $\mathrm{T} * \mathrm{SP}$ & & & \\
\hline level for & 0.10 & 0.13 & 0.15 & & & & 0.11 & 0.14 & 0.17 & & & \\
\hline \multicolumn{13}{|c|}{ Texture $\left(\mathrm{g} / \mathrm{cm}^{2}\right)$} \\
\hline $\begin{array}{l}\mathrm{CaCl}_{2} \text { at } \\
0.05 \% \\
\end{array}$ & 12.24 & 12.06 & 11.87 & 11.52 & 11.17 & 11.77 & 14.06 & 13.72 & 13.41 & 13.10 & 12.82 & 13.42 \\
\hline $\begin{array}{c}\mathrm{Cacl}_{2} \text { at } 1 \\
\%\end{array}$ & 12.24 & 11.60 & 11.12 & 10.65 & 10.06 & 11.13 & 14.06 & 12.69 & 12.00 & 11.62 & 11.43 & 12.36 \\
\hline $\begin{array}{c}\text { Ca-lactate } \\
\text { at } 1 \% \\
\end{array}$ & 12.24 & 12.12 & 11.80 & 11.42 & 11.27 & 11.76 & 14.06 & 13.61 & 13.32 & 13.16 & 12.72 & 13.37 \\
\hline $\begin{array}{c}\text { Ca-lactate } \\
\text { at } 2 \% \\
\end{array}$ & 12.24 & 12.40 & 11.00 & 10.51 & 10.08 & 11.25 & 14.06 & 12.54 & 12.06 & 11.51 & 11.35 & 12.30 \\
\hline $\begin{array}{l}\mathrm{H}_{2} \mathrm{O}_{2} \text { at } \\
0.15 \%\end{array}$ & 12.24 & 11.11 & 11.50 & 11.06 & 10.80 & 11.34 & 14.06 & 13.11 & 12.74 & 12.14 & 11.81 & 12.77 \\
\hline $\begin{array}{c}\mathrm{H}_{2} \mathrm{O}_{2} \text { at } \\
0.3 \% \\
\end{array}$ & 12.24 & 11.62 & 11.12 & 10.68 & 9.72 & 11.08 & 14.06 & 12.51 & 11.87 & 11.31 & 11.06 & 12.16 \\
\hline Cont. & 12.24 & 11.32 & 10.64 & 10.02 & 9.11 & 10.67 & 14.06 & 12.01 & 11.42 & 11.00 & 10.41 & 11.78 \\
\hline Mean & 12.24 & 11.75 & 11.29 & 10.84 & 10.31 & 11.29 & 14.06 & 12.88 & 12.40 & 11.98 & 11.66 & 12.60 \\
\hline LSD at 0.05 & $\mathrm{~T}$ & SP & $\mathrm{T} * \mathrm{SP}$ & & & & $\mathrm{T}$ & SP & $\mathrm{T} * \mathrm{SP}$ & & & \\
\hline level for & 0.13 & 0.17 & 0.22 & & & & 0.11 & 0.14 & 0.19 & & & \\
\hline
\end{tabular}


974 EFFECT OF CALCIUM CHLORIDE, CALCIUM LACTATE AND HYDROGEN PEROXIDE TREATMENTS ON QUALITY OF FRESH CUT CANTALOUPE DURING COLD STORAGE

Table 4 . Effect of Cacl2, Ca- lactate and $\mathrm{H} 2 \mathrm{O} 2$ concentrations on Total sugars $\%$ and Total phenol content of fresh - cut cantaloupe.

\begin{tabular}{|c|c|c|c|c|c|c|c|c|c|c|c|c|}
\hline \multirow{3}{*}{ Treatment ( $T$ ) } & \multicolumn{5}{|c|}{ 2011/2012 } & \multirow{3}{*}{ Mean } & \multicolumn{5}{|c|}{$2012 / 2013$} & \multirow{3}{*}{ Mean } \\
\hline & \multicolumn{5}{|c|}{ Storage period days (SP) } & & \multicolumn{5}{|c|}{ Storage period days (SP) } & \\
\hline & 0 & 3 & 6 & 9 & 12 & & $\mathbf{0}$ & 3 & 6 & 9 & 12 & \\
\hline \multicolumn{13}{|c|}{ Total sugars \% } \\
\hline $\mathrm{CaCl}_{2}$ at $0.05 \%$ & 8.24 & 8.00 & 7.72 & 7.31 & 6.94 & 7.64 & 7.31 & 7.11 & 7.03 & 6.85 & 6.13 & 6.89 \\
\hline $\mathrm{Cacl}_{2}$ at $1 \%$ & 8.24 & 7.91 & 7.64 & 7.23 & 6.85 & 7.57 & 7.31 & 7.03 & 6.92 & 6.50 & 6.03 & 6.76 \\
\hline Ca-lactate at $1 \%$ & 8.24 & 7.84 & 7.45 & 7.10 & 6.72 & 7.47 & 7.31 & 7.06 & 6.81 & 6.32 & 6.00 & 6.70 \\
\hline Ca-lactate at $2 \%$ & 8.24 & 7.50 & 7.11 & 6.85 & 6.13 & 7.17 & 7.31 & 6.82 & 6.54 & 6.03 & 5.80 & 6.50 \\
\hline $\mathrm{H}_{2} \mathrm{O}_{2}$ at $0.15 \%$ & 8.24 & 7.72 & 7.45 & 7.07 & 6.69 & 7.43 & 7.31 & 6.95 & 6.82 & 6.24 & 5.92 & 6.65 \\
\hline $\mathrm{H}_{2} \mathrm{O}_{2}$ at $0.3 \%$ & 8.24 & 7.40 & 7.00 & 6.62 & 6.03 & 7.06 & 7.31 & 6.61 & 6.42 & 5.93 & 5.50 & 6.35 \\
\hline Cont. & 8.24 & 7.25 & 6.84 & 6.30 & 5.72 & 6.87 & 7.31 & 6.46 & 6.00 & 5.41 & 5.03 & 6.04 \\
\hline Mean & 8.24 & 7.66 & 7.32 & 6.93 & 6.44 & 7.32 & 7.31 & 6.86 & 6.65 & 6.18 & 5.77 & 6.56 \\
\hline \multirow[t]{2}{*}{ LSD at 0.05 level } & $\mathrm{T}$ & SP & $\mathrm{T} * \mathrm{SP}$ & & & & $\mathrm{T}$ & SP & $\mathrm{T} * \mathrm{SP}$ & & & \\
\hline & 0.22 & 0.25 & 0.30 & & & & 0.21 & 0.26 & 0.28 & & & \\
\hline \multicolumn{13}{|c|}{ Total phenol content ( $\mathbf{m g} / \mathbf{1 0 0} \mathbf{~ g m ~ F w ) ~}$} \\
\hline $\mathrm{CaCl}_{2}$ at $0.05 \%$ & 10.32 & 10.10 & 9.94 & 9.61 & 8.78 & 9.75 & 9.10 & 9.00 & 8.75 & 8.14 & 7.50 & 8.50 \\
\hline $\mathrm{Cacl}_{2}$ at $1 \%$ & 10.32 & 10.15 & 9.82 & 9.54 & 8.91 & 9.75 & 9.10 & 9.02 & 8.61 & 8.25 & 7.67 & 8.53 \\
\hline Ca-lactate at $1 \%$ & 10.32 & 9.94 & 9.70 & 9.20 & 8.50 & 9.53 & 9.10 & 8.92 & 8.55 & 8.00 & 7.53 & 8.42 \\
\hline Ca-lactate at $2 \%$ & 10.32 & 9.85 & 9.32 & 8.71 & 8.14 & 9.27 & 9.10 & 8.74 & 8.14 & 7.64 & 7.12 & 8.15 \\
\hline $\mathrm{H}_{2} \mathrm{O}_{2}$ at $0.15 \%$ & 10.32 & 9.65 & 9.23 & 8.43 & 8.06 & 9.14 & 9.10 & 8.50 & 8.00 & 7.42 & 7.05 & 8.01 \\
\hline $\mathrm{H}_{2} \mathrm{O}_{2}$ at $0.3 \%$ & 10.32 & 9.75 & 9.03 & 8.27 & 7.93 & 9.06 & 9.10 & 8.67 & 8.10 & 7.37 & 6.92 & 8.03 \\
\hline Cont. & 10.32 & 9.52 & 9.71 & 8.00 & 7.03 & 8.92 & 9.10 & 8.30 & 7.84 & 7.03 & 6.07 & 7.67 \\
\hline Mean & 10.32 & 9.85 & 9.54 & 8.82 & 8.19 & 9.34 & 9.10 & 8.74 & 8.28 & 7.69 & 7.12 & 8.19 \\
\hline LSD at 0.05 level & $\mathrm{T}$ & $\mathrm{SP}$ & $\mathrm{T} * \mathrm{SP}$ & & & & $\mathrm{T}$ & SP & $\mathrm{T} * \mathrm{SP}$ & & & \\
\hline for & 0.14 & 0.15 & 0.18 & & & & 0.13 & 0.16 & 0.19 & & & \\
\hline
\end{tabular}


Table 5. Effect of $\mathrm{CaCl}_{2}$, $\mathrm{Ca}$ - lactate and $\mathrm{H}_{2} \mathrm{O}_{2}$ concentrations on poly phenol oxidase and total microbial count of fresh - cut cantaloupe.

\begin{tabular}{|c|c|c|c|c|c|c|c|c|c|c|c|c|}
\hline \multirow{3}{*}{$\begin{array}{c}\text { Treatment } \\
\text { (T) }\end{array}$} & \multicolumn{5}{|c|}{$2011 / 2012$} & \multirow{3}{*}{ Mean } & \multirow{2}{*}{\multicolumn{5}{|c|}{$\frac{2012 / 2013}{\text { Storage period days (SP) }}$}} & \multirow{3}{*}{ Mean } \\
\hline & \multicolumn{5}{|c|}{ Storage period days (SP) } & & & & & & & \\
\hline & $\mathbf{0}$ & 3 & 6 & 9 & 12 & & $\mathbf{0}$ & 3 & 6 & 9 & 12 & \\
\hline \multicolumn{13}{|c|}{ Poly phenol oxidase (Units/g of fruit/min) } \\
\hline $\begin{array}{l}\mathrm{CaCl}_{2} \text { at } \\
0.05 \%\end{array}$ & 90.20 & 92.30 & 94.60 & 97.30 & 98.30 & 94.54 & 88.20 & 89.40 & 91.50 & 93.40 & 96.40 & 91.78 \\
\hline $\begin{array}{c}\mathrm{Cacl}_{2} \text { at } 1 \\
\%\end{array}$ & 91.20 & 91.90 & 93.80 & 96.50 & 98.50 & 94.38 & 89.30 & 90.20 & 91.60 & 94.30 & 97.50 & 92.58 \\
\hline $\begin{array}{c}\text { Ca-lactate } \\
\text { at } 1 \%\end{array}$ & 93.50 & 96.10 & 98.40 & 99.20 & 100.10 & 97.46 & 94.50 & 95.80 & 93.50 & 96.40 & 99.20 & 95.88 \\
\hline $\begin{array}{c}\text { Ca-lactate } \\
\text { at } 2 \%\end{array}$ & 94.30 & 96.20 & 98.70 & 99.30 & 101.40 & 97.98 & 95.20 & 96.10 & 94.20 & 97.30 & 99.90 & 96.54 \\
\hline $\begin{array}{l}\mathrm{H}_{2} \mathrm{O}_{2} \text { at } \\
0.15 \%\end{array}$ & 96.20 & 97.50 & 100.20 & 102.40 & 104.50 & 100.16 & 97.30 & 98.90 & 100.40 & 102.40 & 103.60 & 100.52 \\
\hline $\begin{array}{c}\mathrm{H}_{2} \mathrm{O}_{2} \text { at } \\
0.3 \%\end{array}$ & 97.10 & 100.70 & 105.10 & 109.50 & 114.20 & 105.32 & 97.50 & 99.20 & 105.30 & 108.40 & 111.70 & 104.42 \\
\hline Cont. & 100.00 & 107.50 & 111.70 & 117.30 & 125.10 & 112.32 & 100.00 & 109.50 & 112.10 & 119.20 & 123.40 & 112.84 \\
\hline Mean & 94.64 & 97.46 & 100.36 & 103.07 & 106.01 & 100.31 & 94.57 & 97.01 & 98.37 & 101.63 & 104.53 & 99.22 \\
\hline \multirow{2}{*}{$\begin{array}{c}\text { LSD at } 0.05 \\
\text { level for }\end{array}$} & $\mathrm{T}$ & $\mathrm{SP}$ & $\mathrm{T} * \mathrm{SP}$ & & & & $\mathrm{T}$ & SP & $\mathrm{T} * \mathrm{SP}$ & & & \\
\hline & 1.24 & 1.62 & 1.94 & & & & 1.43 & 1.75 & 1.92 & & & \\
\hline \multicolumn{13}{|c|}{ Total microbial count ( CFU/ gm ) } \\
\hline $\begin{array}{l}\mathrm{Cacl}_{2} \text { at } \\
0.05 \%\end{array}$ & 0.51 & 0.92 & 1.14 & 1.35 & 1.75 & 1.13 & 0.57 & 1.26 & 1.74 & 1.87 & 2.27 & 1.54 \\
\hline $\begin{array}{c}\mathrm{Cacl}_{2} \text { at } 1 \\
\%\end{array}$ & 0.51 & 0.98 & 1.20 & 1.43 & 1.92 & 1.21 & 0.57 & 1.35 & 1.62 & 1.97 & 2.38 & 1.58 \\
\hline $\begin{array}{c}\text { Ca-lactate } \\
\text { at } 1 \%\end{array}$ & 0.51 & 0.85 & 1.22 & 1.32 & 1.81 & 1.14 & 0.57 & 1.14 & 1.65 & 1.81 & 2.54 & 1.54 \\
\hline $\begin{array}{c}\text { Ca-lactate } \\
\text { at } 2 \%\end{array}$ & 0.51 & 1.24 & 1.65 & 1.72 & 2.14 & 1.45 & 0.57 & 1.41 & 1.92 & 2.41 & 2.71 & 1.80 \\
\hline $\begin{array}{l}\mathrm{H}_{2} \mathrm{O}_{2} \text { at } \\
0.15 \%\end{array}$ & 0.51 & 1.06 & 1.32 & 1.49 & 1.98 & 1.27 & 0.57 & 1.17 & 1.63 & 2.01 & 2.22 & 1.52 \\
\hline $\begin{array}{c}\mathrm{H}_{2} \mathrm{O}_{2} \text { at } \\
0.3 \%\end{array}$ & 0.51 & 1.31 & 1.41 & 1.77 & 2.24 & 1.45 & 0.57 & 1.48 & 1.99 & 2.12 & 2.37 & 1.71 \\
\hline Cont. & 0.51 & 1.75 & 2.25 & 3.34 & 3.97 & 2.36 & 0.57 & 1.87 & 2.34 & 2.88 & 3.68 & 2.27 \\
\hline Mean & 0.51 & 1.16 & 1.46 & 1.77 & 2.26 & 1.43 & 0.57 & 1.38 & 1.84 & 2.15 & 2.60 & 1.71 \\
\hline LSD at 0.05 & $\mathrm{~T}$ & SP & $\mathrm{T}^{*} \mathrm{SP}$ & & & & $\mathrm{T}$ & SP & $\mathrm{T} * \mathrm{SP}$ & & & \\
\hline level for & 0.07 & 0.11 & 0.13 & & & & 0.09 & 0.13 & 0.17 & & & \\
\hline
\end{tabular}




\section{REFERENCES}

1. Altunkaya, A. and V.Gokmen. 2009. Effect of various anti-browning agents on phenolic compounds profile of fresh lettuce (L Sativa ) Food Chemistry, 108: 112 1179.

2. Anese, M.M. and M.C.Nicoli. 1997. Quality of minimally processed apple slice using different modified atmosphere conditions. J.Food Quality, 30:359-370.

3. AOAC. 1990. Official Methods of Analysis .13th Ed. Association of Official Chemists Washington DC. USA.

4. Cantos, E., J.C. Espin and F.A. Tomas-Barberan. 2001. Effect of wounding on phenolic enzyme in six minimally processed lettuce upon storage. J. Agric. and Food Chem. 49:322 - 330.

5. Degrave, P., R.Saurel and Y.Cautel. 2003. Vacuum impregnation pretreatment with pectin methyl esterase to improve firmness of pasteurized fruits. J.Food Sci. 68: 716 $-721$.

6. Dogan ,M., O.Aslan. and S.Dogan. 2002. Substrate specificity, heat inactivation and inhibition of polyphenol oxidase from different aubergine cultivars. Intem. J. Food Scii. Technol., $37: 415-43$.

7. Fallik, E., S.Alkali-Tuvia,Horev., A.Copel, Virodov,Y.Aharoni, D.Ulrich and H.Schulz.(2001). Chracterziation of Galia melon aroma by GC and mass spectrometric sensor measurement after prolonged storage. Postharvest Biol. Technol. 22: 85-91.

8. Francisca, L.C.A., R.E.Alves and F.W.Fgueiredo. 2008. Application of 1methylcyclopropene, calcium chloride and calcium amino acid on fresh- cut cantaloupe muskmelon. Postharvest Biol. Technol. 28: 1- 25.

9. Garcia,E. and Barrett,M. 2002. Preservative treatments for fresh - cut fruits and vegetables. In fresh- cut fruits and vegetables Lamikrana , O. (Ed).CAC Press,N.Y,pp 268- 282.

10. Lamikrana ,O. and M.A.Watson. 2007. Mild heat and calcium treatments effects on fresh- cut cantaloupe melon during storage. Food Chemistry 102: 1383 - 1388.

11. Luna- Guzman, I and D.M.Barrett. 2000. Comparison of calcium chloride and calcium lactate effectiveness in maintaining shelf stability and quality of fresh - cut cantaloupe. Postharvest Biology and Technology. 19 : 61- 72.

12. Mayer, A.M. and E.Harel. 1991. Polyphenoloxidase and their significance in fruit and vegetables. In P.F.Fox, ed., Food Enzymology, v.I, Elsevier, London, pp. 373 - 398.

13. Nelson,N.1974. A photometric adaptation of Somogyi methods for determination of glucose J.Biol. Chem., 159 : 375- 380.

14. Qlusola, L. and M.A.Watson. 2007. Mild heat and calcium treatment effects on fresh - cut cantaloupe melon during storage. Food Chemistry 102 : 1383 - 1388. 
15. Robards, K., P.D.Penzle, G.Tucker,P.Swatsitang and W.Solver. 1999. Phenolic compounds and theire role in oxidative processed in fruits. Food Chemistry ,66 (4): 401-436.

16. Rodrigues, D.A.C., M.G.Miguel., A.M.Cavaco.,S.Dandlen., S.Numes ., and M.D.C. Antunes. 2010. Influnce of citric acid, ascorbic acid and calcium lactate applications on the shelf life of minimally processed horticultural products. Acta Hort., No.858:369- 372.

17. Saftner, R.A., J.Baj, J.A.Abbott and Y.S. Lee. 2003. Sanitary dips with calcium propionates calcium chloride, or calcium amino acid chelates maintain quality and shelf stability of freh- cut honeydew chinks, postharvest Biol. Technol. 29 : 257 269.

18. Sapers, G.M. and K.B.Hicks.1989. Inhibition of enzymatic browning experiment in fruits and vegetables. In quality factors of fruits and vegetables. Food Chemistry, J.Jen (Ed), p.29-43. Am. Chem.Soc.Washington. D.C.

19. Sapers, G.M., R.L.Miler, V.Pilizota and A.M.mattrazzo. 2001. Antimicrobial treatments for minimally processed cantaloupe melon. J. Food Sci. 66: 345 -349.

20. Shelef, L.A. 1994. Antimicrobial effects of lactates : a review. J.Food Prot., 57: 445 450.

21. Snedecor, G.W. and W.G.Cochran. 1980. Statistical methods Lowa State Univ.Press, USA

22. Somogyi,M. 1952. Notes on sugar determination.J.Biol. Chem.,195: 19 -23.

23. Ukuku, D.O. 2004. Effect of hydrogen peroxidase treatment on microbial quality and appearance of whole and fresh- cut melons contaminated with Salmonella spp. International J. food microbiology. 95 : 137- 146.

24. Ukuku, D.O., M.L.Bari., S.Kawamoto and K.Isshiki. 2005. Use of hydrogene peroxide in combination with nisin, sodium lactate and citric acid for reducing transfer of bacterial pathogens from whole melon surfaces to fresh - cut pieces. Inter. J. Food Microbiology. 104 : 225 - 233.

25. Weaver, R. A. and L.A.Shelef. 1993. Antisterial activity of sodium, potassium or calcium lactates in pork liver sausage. J.Food Safety 13:133-146.

26. Wills, R.B.H., T.H.Lee, D.Grahum, W.B.McGlasson and E.G.Hall. 1981. Postharvest, An introduction to physiology and handling of fruits and vegetables. Inc. Westport, Connectiut.

27. Yamaguchi, T., M.Katsuda, Y.Oda, J.Terao, K.Kanazawa and S.Oshima. 2003. Influence of polyphenoloxidase and ascorbate oxidase during cooking process on the radical scarning activity of vegetables. Food Science and Technology Research 9 (1) : 79 -83. 


\section{اثز المعاملة بكلوريد الكالسيوم ، لاكتات الكالسيوم وبيروكسيد الهيدروجين على جودة الكنتالوب المقطع جزئيا خلال التخزين المبرد}

\section{منال محمد عطية}

- قسم بحوث معاملات ما بعد الحصاد وتداول الخضر - معهر بحوث البساتين - مركز البحوث الزراعية

اجريت هذه الدراسة على الكنتالوب (صنف بريمال ) حيث ثم حصاد الثمار فى مرحلة اللون

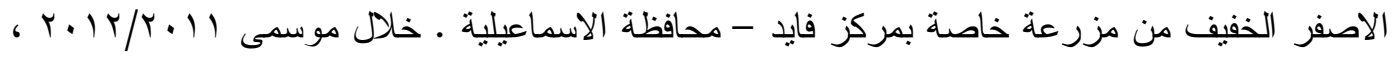

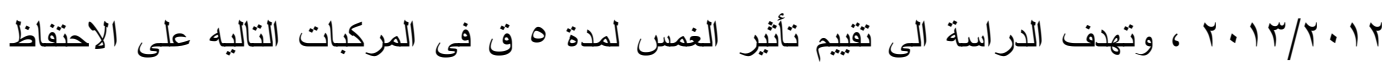
بجودة الكنتالوب المقطع جزئيا.

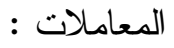

$$
\begin{aligned}
& \text { 1. الغصس فى محلول كلوريد الكالسيوم بتركيزات (0. ، 1\%) . }
\end{aligned}
$$

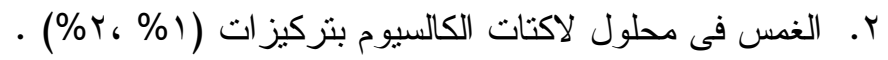

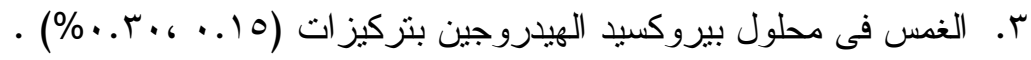

$$
\begin{aligned}
& \text { ع. الغمس فى الماء المقطر (الكنترول) . }
\end{aligned}
$$
وقد اظهرت النتائج ما يلى : المعاء

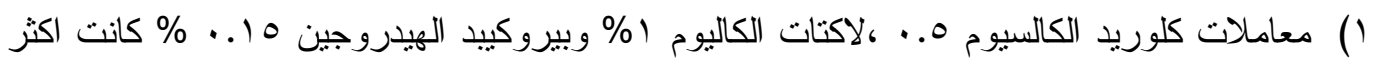

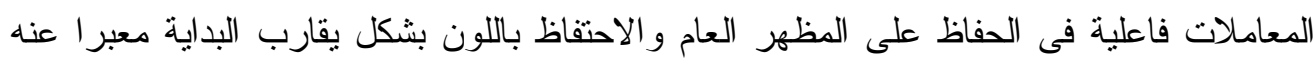
بقيمة ( L, b ) وقللت الفقد فى السكريات الكلية.

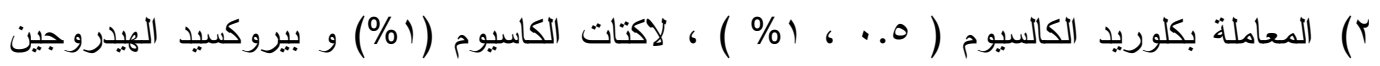

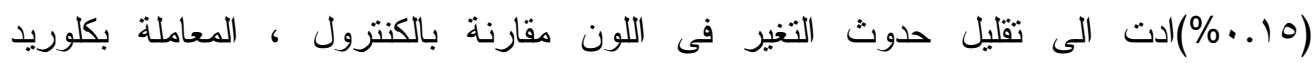

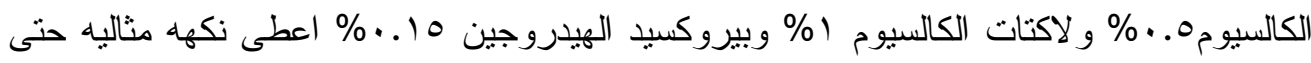

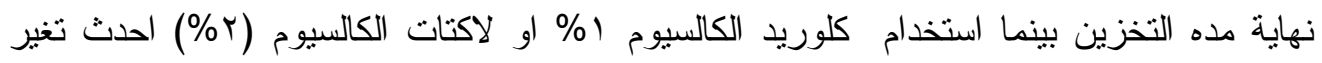

$$
\text { طفيف فى النكهه. }
$$

r) المعاملة بكلوريد الكالسيوم 0. • \% ، لاكتات الكاليوم (\% ادت الى الفقد فى القو ام او حدوث فقد فى

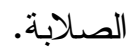

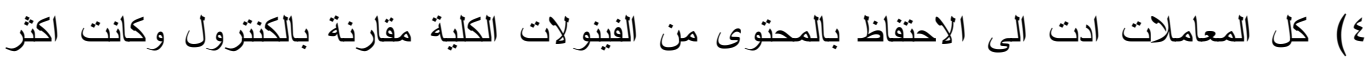

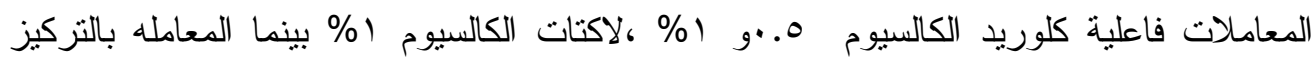

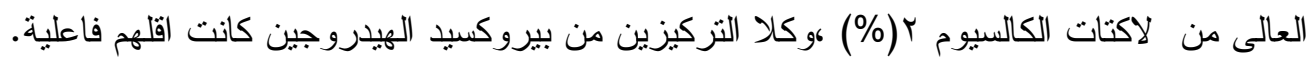

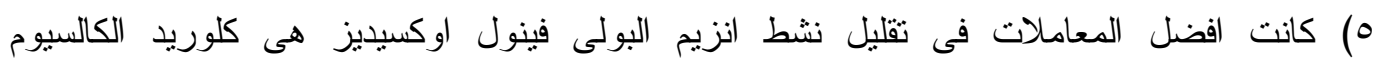

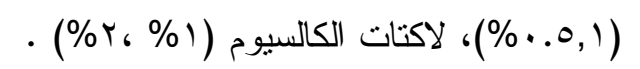

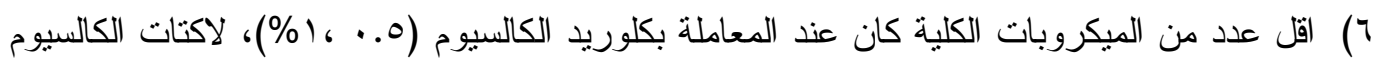

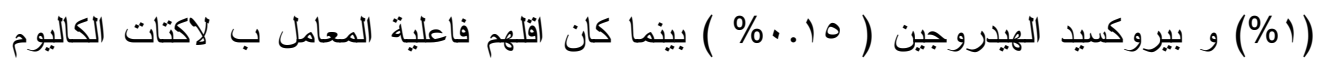

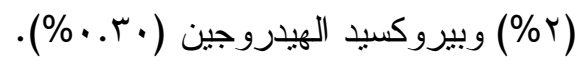

